\section{Oxasetin, a New Antibacterial Polyketide Produced by Fungus Vaginatispora aquatica, HK1821}

\author{
Haiyin He, ${ }^{\dagger, *}$ JefFrey E. Janso, ${ }^{\dagger \dagger}$ Hui Y. Yang, ${ }^{\dagger}$ \\ Maya P. Singh, ${ }^{\dagger \dagger}$ Valerie S. Bernan, ${ }^{\dagger \dagger}$ \\ Michael Greenstein $^{\dagger \dagger}$ and Guy T. CARTER ${ }^{\dagger}$ \\ ${ }^{\dagger}$ Department of Natural Products Chemistry, Chemical Sciences \\ and ${ }^{\dagger \dagger}$ Department of Microbiology, Infectious Disease Research, \\ Wyeth Research, \\ 401 N. Middletown Road, \\ Pearl River, NY 10965, U.S.A.
}

(Received for publication May 13, 2002)

The rapid increase in bacterial resistance to antibiotics in clinical practice has prompted renewed efforts to discover new types of antibacterial agents. ${ }^{1}$ In our continuing search for new antibiotics from microorganisms, we examined a number of fungal cultures that were either recently acquired by our laboratory or fermented by unconventional methods. ${ }^{2)}$ The fungus HK1821 was isolated from a decaying piece of wood submerged in the Lam Tsuen River in Tai Po, Hong Kong. Through comparison of the ITS in GenBank, it was found to be highly related to Vaginatispora aquatica. ${ }^{3)}$ In antimicrobial screening, methicillin-resistant Staphylococcus aureus and vancomycin-resistant Enterococcus faecalis were shown to be susceptible to the culture whole broth of HK1821. A new 2-oxo-succinimide polyketide, designated oxasetin (1), was isolated from the fermentation broth and was found to be responsible for the antibacterial activity. In this paper the production, structure, and biological activity of $\mathbf{1}$ are reported.

\section{Identification of HK1821 as Vaginatispora aquatica}

Genomic DNA was isolated from mycelia of an agar grown culture of HK1821 by a phenol/chloroform extraction. The internally transcribed spacer region $1,5.8 \mathrm{~S}$ rDNA, and the internally transcribed spacer region 2 (ITS15.8S-ITS2) were PCR-amplified. The purified PCR product was sequenced directly on an Applied Biosystems ABI 3700 sequencer. After editing in Sequencher ${ }^{\mathrm{TM}}$ version 4.0 .5 , the ITS of HK1821 was found to be $484 \mathrm{bp}$ in length. A nucleotide Blast search (NCBI 2.2) was performed to compare this sequence to other sequences in the GenBank database. The analysis revealed that the ITS of HK1821 is most similar to the ITS of Vaginatispora aquatica (GenBank accession AF383968) followed by several Massarina sp. and Lophiostoma sp., which are all members of the Lophiostomaceae. An alignment of the ITS of HK1821 with Vaginatispora aquatica in BestFit indicated that they are $99.6 \%$ identical with only three mismatched base pairs; there is a $\mathrm{C} / \mathrm{T}$ transition at position 55 in the ITS 1 , and there are two single base deletions in the ITS of HK1821; one at position 45 in the ITS 1 and the other at position 442 in the ITS 2.

Apparently; these two organisms have only recently diverged. A difference in the ITS of about $0.5 \%$ is well within the bounds of intraspecific variation found amongst other genera of fungi. ${ }^{5)}$ However, it is not enough variation to state that HK1821 and Vaginatispora aquatica (AF383968) are distinct species. Therefore, we propose that HK1821 is a Vaginatispora aquatica isolate.

HK1821 was plated onto potato dextrose agar (PDA) (Difco) and cornmeal agar (CMA) (Oxoid) to observe morphology. The plates were incubated at room temperature (about $22^{\circ} \mathrm{C}$ ) with a natural light cycle, and morphology was noted every seven days. On PDA, HK1821 grew about nine millimeters per week. The colonies were velvety and mounded in the first two weeks and became more fleece-like with age. The young colonies were light gray to buff in color and darkened to a dark taupe after one month. A yellow soluble pigment was visible in the agar after two weeks incubation. Fruiting bodies were visible after one month and formed at the base of the petri dish as described by HYDE. ${ }^{3)}$ Although the fruiting structures were about 0.3 to 0.5 millimeters in diameter, spores were not produced within the fruiting bodies even after two months incubation.

On CMA, HK1821 grew at about eight millimeters per week. In contrast to the dense, mounded growth of HK1821 on PDA, the growth on CMA was much thinner. After two weeks of growth, the mycelia were furry or fuzzy and pigmented olivaceous; they became more gray and fleecelike with age. No fruiting bodies or soluble pigment were observed after two months incubation.

\section{Production, Structure, and Antibacterial} Activity of Oxasetin (1)

The fungal culture HK1821 was plated onto Bennett's

* Corresponding author: heh@wyeth.com 
medium from frozen stock and was incubated at $22^{\circ} \mathrm{C}$ until there was sufficient mycelial growth to inoculate into the first stage seed. The culture was transferred into a $25 \times 150 \mathrm{~mm}$ tube, containing $11 \mathrm{ml}$ of Difco potatodextrose broth. The tube was shaken at $160 \mathrm{rpm}$ at $22^{\circ} \mathrm{C}$ for 4 days. The first stage seed was transferred to a $250 \mathrm{ml}$ Erlenmeyer flask containing $45 \mathrm{ml}$ of potato - dextrose broth at $\mathrm{pH}$ 7.0. The second stage seed was incubated at $22^{\circ} \mathrm{C}$ with shaking at $200 \mathrm{rpm}$ for an additional 4 days and was then inoculated into a 2.8-liter Fernbach flask containing 1 liter of potato-dextrose broth at $\mathrm{pH} \mathrm{7.0.} \mathrm{The} \mathrm{fermentation}$ was carried out under the same conditions as the second stage seed. The antibacterial activity was monitored by the agar diffusion method $^{6)}$ and peaked after 10 days.

The whole broth of the 10-day fermentation (1 liter) was centrifuged, and the cells and supernatant were respectively extracted with methanol and ethyl acetate. The combined organic extract was concentrated under reduced pressure to give a reddish residue. This residue was chromatographed by reverse phase HPLC on a $\mathrm{C} 18$ column using a linear gradient of $90 \sim 100 \%$ acetonitrile in water containing $0.02 \%$ trifluoroacetic acid (TFA) to obtain oxasetin (1) (85.5 mg, physico-chemical data see Table 1).

The molecular formula of $\mathbf{1}$ was determined to be $\mathrm{C}_{21} \mathrm{H}_{29} \mathrm{NO}_{4}$ by high-resolution Fourier transform ion cyclotron resonance (FTICR) mass spectrometry. The ${ }^{13} \mathrm{C}$ NMR spectrum (Figure 2) displayed the signal of a keto group at $\delta 200.2$, in addition to $6 s p^{2}$ carbon signals in the range between 106.3 and 171.7 . The ${ }^{13} \mathrm{C}$ signals in the aliphatic region were assigned by DEPT experiments to 4 methyls, 5 methylenes, 4 methines, and 1 quaternary carbon. In the ${ }^{1} \mathrm{H}$ NMR spectrum (Figure 3), resonances of 2 methyl singlets, 1 methyl doublet, and 1 methyl triplet were observed. The signals at $\delta 5.07$ and $10.75\left(\mathrm{D}_{2} \mathrm{O}\right.$ exchangeable) were respectively assigned to an olefinic and an amide proton.

The analysis of 2-D COSY and TOCSY data revealed the homonuclear spin system of $\mathrm{H}-14$ at $\delta 2.58, \mathrm{H}_{2}-15$ at 1.36 and $1.04, \mathrm{H}_{2}-16$ at 1.14 and 1.03 , and $\mathrm{H}_{3}-17$ at 0.70 . In an HMBC spectrum, the strong 2- or 3-bond correlations between 5-Me at $\delta 1.13$ and $\mathrm{C}-4$ at $200.2, \mathrm{C}-5$ at $51.7, \mathrm{C}-6$ at 40.6 , and $\mathrm{C}-14$ at 45.1 , between $13-\mathrm{Me}$ at $\delta 1.63$, and C12 at $124.8, \mathrm{C}-13$ at 134.1, and C-14, between 9-Me at $\delta$ 0.85 and $\mathrm{C}-8$ at $35.6, \mathrm{C}-9$ at 32.9 , and $\mathrm{C}-10$ at 42.0 , and between $\mathrm{H}-12$ at $\delta 5.07$ and $\mathrm{C}-6$ at $40.6, \mathrm{C}-8, \mathrm{C}-11$ at 38.6, $\mathrm{C}-13$, and $\mathrm{C}-14$ signals were observed. These correlations,

Fig. 1. Structure of oxasetin (1).

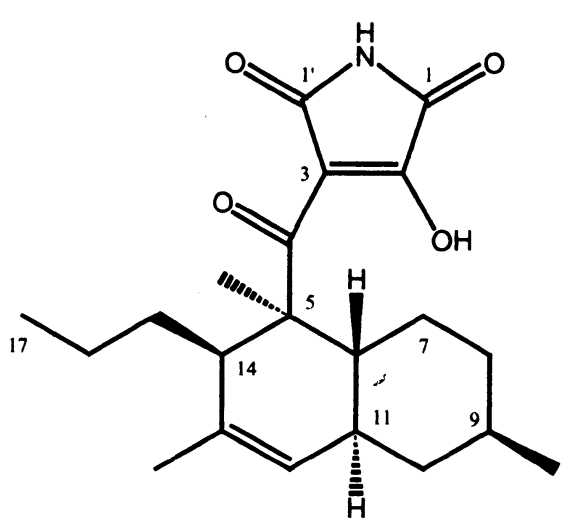

Fig. 2. ${ }^{13} \mathrm{C}$ NMR spectrum of $1\left(100 \mathrm{MHz}, \mathrm{DMSO}-d_{6}\right)$.

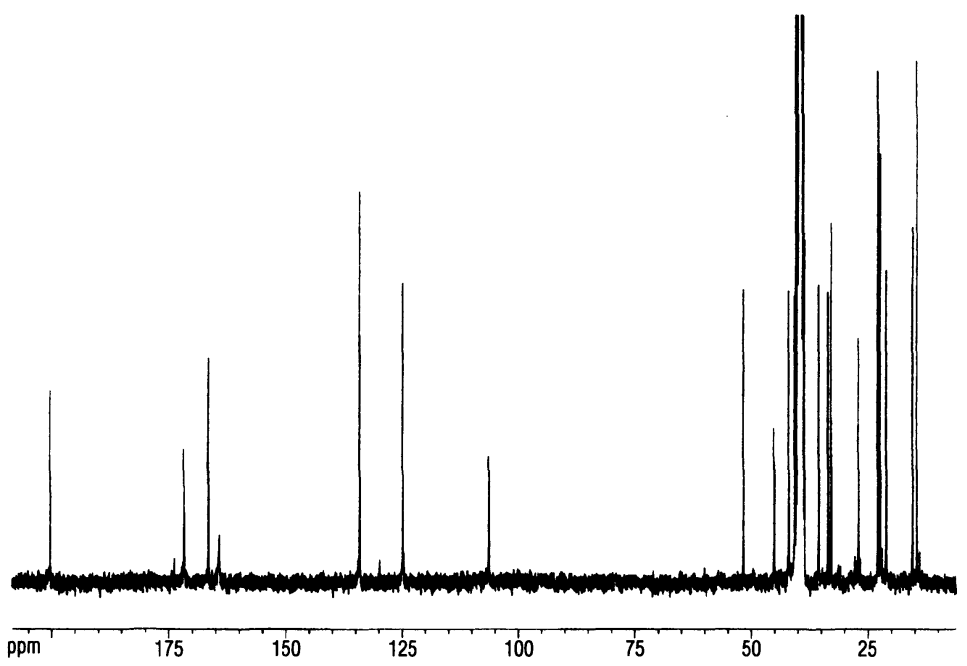


Fig. 3. ${ }^{1} \mathrm{H}$ NMR spectrum of $1\left(400 \mathrm{MHz}, \mathrm{DMSO}-d_{6}\right)$.

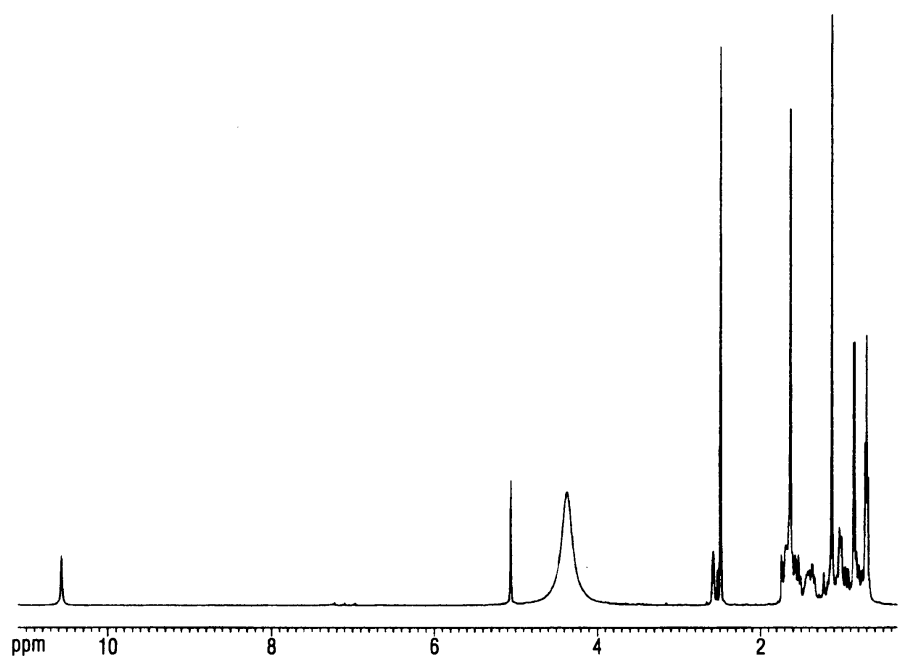

together with weaker 2-bond cross-peaks between C-7 at $\delta$ 27.1 and $\mathrm{H}-6$ at 1.55 and $\mathrm{H}_{2}-8$ at 1.67 and 0.95 , led to the unambiguous assignment for the octahydronaphthalene moiety.

The remaining 4 carbon signals at $\delta 171.7,166.5,164.2$, and 106.3 were all correlated to the amide proton at 10.75 in the HMBC spectrum, which was attributed to the presence of a 2-oxo-succinimide moiety connecting to the $\mathrm{C}-4$ keto group. The assignments of ${ }^{1} \mathrm{H}$ and ${ }^{13} \mathrm{C}$ NMR spectral data and HMBC cross-peaks are listed in Table 2.

The relative stereochemistry of oxasetin (1) was determined by analysis of nuclear Overhauser effects (nOes). In a ROESY spectrum, the strong cross-peaks between $\mathrm{H}-9$ at $\delta 1.44$ and $\mathrm{H}-11$ at 1.64, between $\mathrm{H}-11$ and 5 -Me at 1.13 and between $5-\mathrm{Me}$ and $\mathrm{H}-14$ at 2.58 were observed. These data suggested that the ring junction of the octahydronaphthlene system was trans, the 5-methyl was down, and the 9-methyl and 14-propyl were up (Figure 4).

Oxasetin (1) exhibited moderate in vitro activity against Gram-positive bacteria, including methicillin-resistant Staphylococcus aureus and vancomycin-resistant Enterococcus faecalis. Oxasetin showed no activity against the Gram-negative bacterium Escherichia coli and the yeast Candida albicans. MIC data obtained by the broth dilution method are listed in Table 3.

Oxasetin is structurally related to other fungal metabolites, the glycoside BU-4514N $\mathrm{N}^{7}$ and the enantiomeric homologs, equisetin ${ }^{8)}$ and phomasetin, ${ }^{9)}$ which are all 3-oxo- $\gamma$-lactam polyketides. Equisetin and phomasetin
Table 1. Physico-chemical data of $\mathbf{1}$.

\begin{tabular}{|c|c|c|}
\hline \multirow{4}{*}{$\begin{array}{l}\text { Appearance } \\
\text { Molecular formula } \\
\text { Molecular weight } \\
\text { HRFTICRMS (neg, } m / z \text { ) }\end{array}$} & & Colorless oil \\
\hline & & $\mathrm{C}_{21} \mathrm{H}_{29} \mathrm{NO}_{4}$ \\
\hline & & 359 \\
\hline & $\begin{array}{l}\text { found } \\
\text { Calcd }\end{array}$ & $\begin{array}{l}358.20179(\mathrm{M}-\mathrm{H})^{-} \\
358.20183\end{array}$ \\
\hline $\mathrm{UV} \lambda_{\max }(\mathrm{MeOH}, \mathrm{nm})$ & & $345,261,225$ \\
\hline IR $v_{\max }\left(\mathrm{CHCl}_{3}, \mathrm{~cm}^{-1}\right)$ & & $\begin{array}{l}2952,2923,2868,1782 \\
1726,1625,1562,1454 \\
1408,1341,1162,1025\end{array}$ \\
\hline$[\alpha]_{D}(\mathrm{MeOH})$ & & -147.5 (c 0.367$)$ \\
\hline
\end{tabular}

exhibit inhibitory activity to HIV-1 integrase. ${ }^{9)}$ Although the 3-oxo-succinimide is contained in many synthetic compounds as a pharmacophore, oxasetin is the first example of a natural product to bear this moiety. Biosynthetically, oxasetin is likely to derive from polyketide and amino acid origins. The labeling experiments designed to study its biosynthesis pathway are currently underway.

\section{Acknowledgments}

The authors wish to thank Dr. Kevin Hyde, Hong Kong University, for the fungus HK1821, Dr. XIDONG FENG for highresolution MS measurements, ANDY SCHORK for IR and UV data, and Pete Petersen for MIC data. 
Table 2. ${ }^{1} \mathrm{H}$ and ${ }^{13} \mathrm{C}$ NMR spectral data of $\mathbf{1}$ in DMSO- $d_{6}$.

\begin{tabular}{|c|c|c|c|}
\hline Atom & $\frac{{ }^{1} \mathrm{H}}{(400 \mathrm{MHz}, \text { mult, } J \text { in } \mathrm{Hz})}$ & $\left({ }^{13} \mathrm{C}\right.$ & $\begin{array}{c}\mathrm{HMBC} \\
(J=8 \mathrm{~Hz})\end{array}$ \\
\hline 1 & & $171.7(\mathrm{C})$ & \\
\hline 2 & & $164.2^{\mathrm{a}}(\mathrm{C})$ & \\
\hline 3 & & $106.3(\mathrm{C})$ & \\
\hline 4 & & $200.2(\mathrm{C})$ & \\
\hline 5 & & $51.7(\mathrm{C})$ & \\
\hline 5-Me & $1.13(3 \mathrm{H}, \mathrm{s})$ & $15.5\left(\mathrm{CH}_{3}\right)$ & $C-4, C-5, C-6, C-14$ \\
\hline 6 & $1.55(\mathrm{~m})$ & $40.6(\mathrm{CH})$ & $\mathrm{C}-5,5-\mathrm{Me}, \mathrm{C}-7, \mathrm{C}-8, \mathrm{C}-10, \mathrm{C}-11$ \\
\hline \multirow[t]{2}{*}{7} & $0.82(\mathrm{~m})$ & $27.1\left(\mathrm{CH}_{2}\right)$ & $\mathrm{C}-8, \mathrm{C}-11$ \\
\hline & $1.58(\mathrm{~m})$ & & C-9 \\
\hline \multirow[t]{2}{*}{8} & $0.95(\mathrm{~m})$ & $35.6\left(\mathrm{CH}_{2}\right)$ & C-7, C-9 \\
\hline & $1.67(\mathrm{~m})$ & & C-6, C-7, C-9 \\
\hline 9 & $1.44(\mathrm{~m})$ & $32.9(\mathrm{CH})$ & \\
\hline 9-Me & $0.85(3 \mathrm{H}, \mathrm{d}, 6.4)$ & $22.4\left(\mathrm{CH}_{3}\right)$ & $\mathrm{C}-8, \mathrm{C}-9, \mathrm{C}-10$ \\
\hline \multirow[t]{2}{*}{10} & $0.71(\mathrm{~m})$ & $42.0\left(\mathrm{CH}_{2}\right)$ & $\mathrm{C}-9, \mathrm{C}-11$ \\
\hline & $1.72(\mathrm{~m})$ & & $\mathrm{C}-6, \mathrm{C}-8, \mathrm{C}-9, \mathrm{C}-11$ \\
\hline 11 & $1.64(\mathrm{~m})$ & $38.6(\mathrm{CH})$ & $\mathrm{C}-7$ \\
\hline 12 & 5.07 (br s) & $124.8(\mathrm{CH})$ & $\mathrm{C}-6, \mathrm{C}-10, \mathrm{C}-11,13-\mathrm{Me}, \mathrm{C}-14$ \\
\hline 13 & & $134.1(\mathrm{C})$ & \\
\hline 13-Me & $1.63(3 \mathrm{H}, \mathrm{s})$ & $22.8\left(\mathrm{CH}_{3}\right)$ & C-12, C-13, C-14 \\
\hline 14 & $2.58(\mathrm{~m})$ & $45.1(\mathrm{CH})$ & $\mathrm{C}-5,5-\mathrm{Me}, \mathrm{C}-12, \mathrm{C}-13,13-\mathrm{Me}$ \\
\hline \multirow[t]{2}{*}{15} & $1.04(\mathrm{~m})$ & $33.6\left(\mathrm{CH}_{2}\right)$ & C-13, C-16 \\
\hline & $1.36(\mathrm{~m})$ & & C-5, C-13, C-14, C-16, C-17 \\
\hline \multirow[t]{2}{*}{16} & $1.03(\mathrm{~m})$ & $21.1\left(\mathrm{CH}_{2}\right)$ & $\mathrm{C}-14, \mathrm{C}-15, \mathrm{C}-17$ \\
\hline & $1.14(\mathrm{~m})$ & & C- $15, \mathrm{C}-17$ \\
\hline 17 & $0.70(3 \mathrm{H}, \mathrm{t}, 7.0)$ & $14.5\left(\mathrm{CH}_{3}\right)$ & $C-15, C-16$ \\
\hline $1^{\prime}$ & & $166.5^{\mathrm{a}}(\mathrm{C})$ & \\
\hline $\mathrm{NH}$ & $10.75^{b}(\mathrm{~s})$ & 00.010 & $\mathrm{C}-1^{\prime}, \mathrm{C}-1, \mathrm{C}-2, \mathrm{C}-3$ \\
\hline
\end{tabular}

Fig. 4. Relative stereochemistry of $\mathbf{1}$.

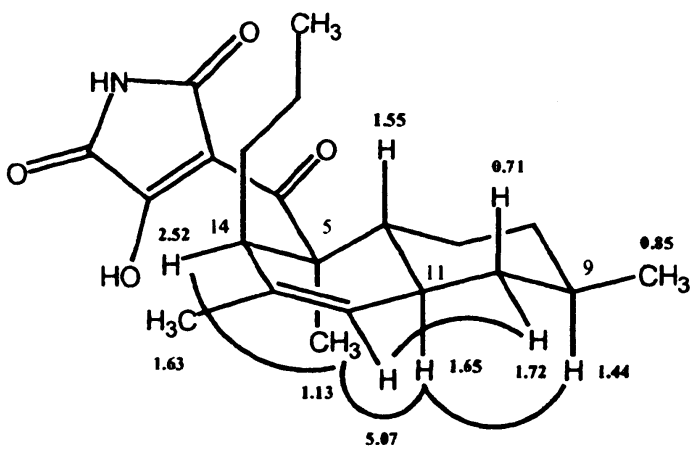

Selected ROESY cross-peaks are indicated. 
Table 3. Antimicrobial activity of $\mathbf{1}$.

\begin{tabular}{lc}
\hline \multicolumn{1}{c}{ Test organism } & $\mathrm{MIC}(\mu \mathrm{g} / \mathrm{ml})^{\mathrm{a}}$ \\
\hline $\begin{array}{l}\text { Staphylococcus aureus (3 strains, } \\
\text { including a methicillin-resistant strain) }\end{array}$ & 16 \\
$\begin{array}{l}\text { Enterococcus faecalis (2 strains, } \\
\text { including a vancomycin-resistant strain) }\end{array}$ & 16 \\
Streptococcus pneumoniae (2 strains) & $16-32$ \\
Escherichia coli & $>128$ \\
Candida albicans & $>128$ \\
\hline${ }^{\mathrm{a}}$ Microbroth dilution method in Mueller-Hinton II, incubated at $35^{\circ} \mathrm{C}$ for 18 hours.
\end{tabular}

\section{References}

1) Breithaupt, H.: The new antibiotics. Nat. Biotechnol. 17(12): 1165 1169, 1999, and the references therein

2) He, H.; H. Y. Yang, R. Bigelis, E. H. Solum, M. Greenstein \& G. T. CARTER: Pyrrocidines A and B, new antibiotics produced by a filamentous fungus. Tetrahedron Letters 43(9): 1633 1636, 2002

3) Hyde, K. D.: Tropical Australian freshwater fungi. IX. Vaginatispora aquatica gen. et sp. nov. Nova Hedwigia 61(1-2): 233 241, 1995

4) LiEw, E. C. Y.; A. Aptroot \& K. D. HydE: An evaluation of the monophyly of Massarina based on ribosomal DNA sequences. Mycologia, in press

5) Arenal, F.; G. Platas, E. Monte \& F. Pelaez: ITS sequencing support for Epicoccum nigrum and Phoma epicoccina being the same biological species. Mycological Research 104(3): 301 303, 2000

6) Singh, M. P.; J. E. JANSO, S. W. LuCKMAN, S. F. Brady, J. Clardy, M. Greenstein \& W. M. Maiese: Biological activity of guanacastepene, a novel diterpenoid antibiotic produced by an unidentified fungus CR115. J. Antibiotics 53: 256 261, 2000
7) Toda, S.; S. Yamamoto, O. Tenmyo, T. Tsuno, T. Hasegawa, M. Rosser, M. OKa, Y. Sawada \& M. KoNISHI: A new neuritogenetic compound, BU-4514N, produced by Microtetraspora sp. J. Antibiotics 46: 875 883, 1993

8) a) Hazuda, D.; C. U. Blau, P. Felock, J. Hastings, B. Pramanik, A. Wolfe, F. Bushman, C. Farnet, M. Goetz, M. Williams, K. Silverman, R. Lingham \& S. SINGH: Isolation and characterization of novel human immunodeficiency virus integrase inhibitors from fungal metabolites. Antiviral Chemistry and Chemotherapy 10(2): 63 70, 1999 Mar.

b) YUKI, K.; M. SHINDO \& K. SHISHIDO: Enantioselective total synthesis of (-)-equisetin using a Me3Al-mediated intramolecular Diels-Alder reaction. Tetrahedron Letters 42(13): 2517 2519, 2001

9) Singh, S. B.; D. L. ZINK, M. A. Goetz, A. W. DOMBrowsKi, J. D. POLISHOOK \& D. J. HAZUDA: Equisetin and a novel opposite stereochemical homolog phomasetin, two fungal metabolites as inhibitors of HIV1 integrase. Tetrahedron Letters 39(16): 2243 2246, 1998 